\title{
PERAN LEMBAGA CATATAN SIPIL TERHADAP PERKAWINAN CAMPURAN BERDASARKAN UNDANG-UNDANG PERKAWINAN*
}

\author{
Laurensius Arliman S \\ Sekolah Tinggi Ilmu Hukum Padang \\ Jalan Gang Mesjid Baiturahman No. 40, Lubuk Lintah, Padang \\ e-mail: laurensiusarliman@gmail.com
}

\begin{abstract}
The legal aspect of civil registration is to obtain as much legal certainty as possible about personal events. Civil registration institutions are government institutions, the state administrative agency in charge, serves to record all family events and has the right, the authority to issue provisions in the field of population and citizenship. As a result of recording and publishing the provision, it has a legal connection with one's civil status or individual law. With the enactment of Law 1 of 1974 concerning Marriage and PP 9 of 1975 as implementing regulations, the public needs for Civil Registry Institutions are increasingly important. Research on this scientific work was a type of normative legal research. Civil records had carried out the tasks carried out by the state well, namely by serving each party who will report the mixed marriages carried out by the parties as well as possible, which is a problem is the lack of public awareness of the importance of the reporting. The implementation of mixed marriages can be carried out if the parties have fulfilled all the requirements determined by the law as contained in Article 60 Paragraph (1) of Law 1 Year 1974. Whereas the Record Institution was only tasked to record the mixed marriage events. Every legal act carried out by any particular person has an impact or effect both for himself and for the other party. No exception in mixed marriages is the legal consequences that arise, both for mixed marriages and for children born from the mixed marriages.
\end{abstract}

Keywords: Civil Registry Institution; Mixed Marriage; Marriage Law.

\begin{abstract}
Abstrak
Aspek hukum dari catatan sipil adalah untuk memperoleh suatu kepastian hukum yang sebesar-besarnya tentang peristiwa-peristiwa pribadi. Lembaga catatan sipil adalah lembaga pemerintahan, lembaga administrasi negara yang bertugas, berfungsi mencatat segala peristiwa keluarga dan berhak, berwenang menerbitkan ketetapan dalam bidang kependudukan dan kewarganegaraan. Akibat dari pencatatan dan penerbitan ketetapan tersebut, mempunyai kaitan hukum dengan status keperdataan seseorang atau hukum perorangan. Dengan berlakunya UU 1 Tahun 1974 tentang Perkawinan dan PP 9 Tahun 1975 sebagai peraturan pelaksananya, maka kebutuhan masyarakat akan Lembaga Catatan Sipil semakin penting. Penelitian karya ilmiah ini, berjenis penelitian hukum normatif. Catatan sipil telah melakukan tugas yang diembankan oleh negara dengan baik, yaitu dengan cara melayani setiap pihak yang akan melaporkan perkawinan campuran yang dilakukan oleh para pihak dengan sebaik-baiknya, yang jadi permasalahan adalah kurang kesadaran masyarakat akan arti pentingnya pelaporan tersebut. Pelaksanaan perkawinan campuran dapat dilakukan apabila para pihak telah memenuhi semua persyaratan yang ditentukan oleh undang-undang sebagaimana yang terdapat dalam Pasal 60 Ayat (1) UU 1 Tahun 1974. Sedangkan Lembaga Catatan hanya bertugas untuk mencatatkan peristiwa perkawinan campuran tersebut. Setiap perbuatan hukum yang dilakukan oleh setiap orang tertentu saja mempunyai dampak atau akibat baik itu bagi dirinya ataupun bagi pihak lainnya. Tidak terkecuali dalam perkawinan campuran ada akibat hukum yang ditimbulkannya, baik itu bagi pihak-pihak pelaku perkawinan campuran maupun bagi anak yang lahir dari perkawinan campuran tersebut.
\end{abstract}

Kata Kunci: Lembaga Catatan Sipil; Perkawinan Campuran; Undang-Undang Perkawinan.

\footnotetext{
* Naskah diterima: 27 Maret 2018, direvisi: 19 Maret 2019, disetujui untuk terbit: 26 Maret 2019

Doi: $\underline{10.3376 / j c h . v 4 i 2.40}$
} 


\section{PENDAHULUAN}

Menurut kodratnya manusia selalu hidup bersama dan individu memiliki jiwa yang menyadari kebutuhan manusia untuk hidup bermasyarakat dilandasi karena didorong oleh kekuatan biologis yang merupakan naluri manusiawi, seperti keinginan untuk memiliki keturunan. Memiliki keturunan adalah keinginan dari setiap manusia dimana disitu mereka bisa menemukan kebahagiaan. Dan satusatunya cara yang bisa dilakukan manusia untuk bisa memiliki keturunan adalah dengan membentuk keluarga yang bahagia dan dirahmati oleh Allah SWT, dan hal tersebut dilakukan melalui perkawinan. Perikatan perkawinan sangat penting dalam pergaulan masyarakat, bahkan hidup bersama ini yang kemudian melahirkan keturunan mereka yang merupakan sendi utama dari pembentukan negara dan bangsa (Laurensius Arliman S, 2015). Perkawinan telah membentuk suatu kesatuan masyarakat terkecil yang disebut keluarga atau rumah tangga. Sebaliknya rusak dan kacaunya suatu keluarga ini akan menimbulkan kekacauan dalam tatanan masyarakat sendiri. Mengingat peranan yang dimiliki oleh hidup bersama itu sangat penting bagi teguh dan sejahteranya masyarakat, maka negara membutuhkan tata tertib dan kaidah-kaidah yang mengatur hidup bersama ini. Dan dari peraturan inilah timbul suatu pengertian dari perkawinan yaitu hidup bersama dari seseorang lakilaki san seorang perempuan yang memenuhi syarat-syarat yang termasuk dalam peraturan tersebut (Rahmat Fauzi, 2018). Tata tertib dan kaidah-kaidah inilah yang berlaku di Indonesia dalam bentuk hukum perkawinan atau istilah lainnya yang sama yang telah berlaku sejak dahulu sampai sekarang.

Tata tertib dan kaidah-kaidah inilah yang dirumuskan dalam Undang-Undang Nomor 1 Tahun 1974 Tentang Perkawinan (UU 1 tahun 1974) dengan peraturan berdasarkan Peraturan Pemerintah Nomor 9 Tahun 1975 (PP 7 Tahun 1975). Dengan adanya peraturan ini maka secara yuridis formal telah berlaku suatu hukum nasional yang mengatur masalah perkawinan di Indonesia. UU 1 tahun 1974 merupakan unifikasi dalam bidang administrasi hukum perkawinan (Yunita, 2008). Hal ini berarti semua mengenai perkawinan diharapkan dapat diatasi dengan adanya peraturan ini maka secara yuridis formal telah berlaku suatu hukum nasional yang mengatur masalah perkawinan di Indonesia. UU 1 tahun 1974 merupakan unifikasi dalam bidang administrasi hukum perkawinan. Hal ini berarti semua masalah mengenai perkawinan diharapkan dapat diatasi dengan menggunakan peraturan hukum perkawinan ini. Adapun pengertian perkawinan menurut UU 1 tahun 1974 sebagaimana yang terdapat dalam Bab 1 Pasal 1 "Perkawinan adalah ikatan lahir bathin antara seorang pria dan seorang wanita sebagai suami istri dengan tujuan membentuk keluarga (rumah tangga) yang bahagia dan kekal berdasarkan Ketuhanan Yang Maha Esa".

Perkawinan merupakan sesuatu yang sakral (Fauzi, 2018), dan diharapkan dari 
Laurensius Arliman S: Peran Lembaga Catatan Sipil Terhadap Perkawinan Campuran...

perkawinan tersebut tercipta suatu keluarga yang sakinah, mawaddah dan warahmah seperti yang terdapat di dalam pengertian perkawinan tersebut. Hal ini tidak jauh berbeda dengan tujuan dari perkawinan yang terdapat dalam $\mathrm{Al}$ Qur'an sendiri. Masyarakat Indonesia merupakan masyarakat yang heterogen dalam segala aspeknya, baik dalam aspek agama maupun adat istiadat (Salim HS, 2002). Tidak berbeda dengan wilayah lainnya di Indonesia, Sumatera Barat memiliki keanekaragaman penduduk baik itu dikarenakan menetapnya orang asing, orang-orang keturunan (cina, arab, india) ataupun orang dari daerah lain yang datang karena suatu tugas, mencari penghidupan maupun untuk belajar.

Hal-hal semacam ini membuka kemungkinan bagi orang untuk mengikatkan diri dalam suatu ikatan yang disebabkan karena pergaulan hidup sehari-hari antara penduduk asli dengan para pendatang (Jasmir, 2018). Adanya mobilitas perpindahan penduduk dari suatu tempat ke tempat lainnya ini sering menyebabkan terjadinya perkawinan diantara penduduk asli dengan pendatang tadi. Bertitik tolak dari kondisi ini maka hukum perkawinan mengambil posisi yang sangat penting. Untuk pelaksanaannya diperlukan suatu perangkat hukum yang dapat memberikan kepastian hukum apabila terjadi suatu perkawinan. Perkawinan merupakan suatu hal yang mempunyai akibat yang luas di dalam hubungan hukum suami istri. Dengan perkawinan timbul suatu ikatan yang berisi tentang hak dan kewajiban.
Suatu hal yang sangat penting adalah bahwa dengan perkawinan itu si istri seketika tidak dapat bertindak sendiri.

Pada saat sekarang ini sudah banyak terjadi perkawinan yang tidak hanya terjadi antara sesama warga negara Indonesia dengan orang warga negara yang berasal dari negara lain. Hal ini pada mulanya banyak terjadi pada kalangan selebritis di Indonesia, tapi sekarang ini masyarakat yang berasal dari golongan masyarakat biasa juga ada yang melakukannya, dan hal tersebut menjadi suatu kebanggaan tersendiri bagi masyarakat atau pihak yang melakukan perkawinan semacam itu (Damayanti, 2015). Perkawinan yang dilakukan dengan warga negara asing inilah yang dinamakan perkawinan campuran. Mengenai perkawinan campuran ini di atur dalam UU 1 tahun 1974 sebagaimana disebutkan dalam Pasal 57, perkawinan campuran adalah perkawinan antara dua orang di Indonesia tunduk pada hukum yang berlainan, karena perbedaan kewarganegaraan dan salah satu pihak berkewarganegaraan asing dan salah satu pihak berkewarganegaraan Indonesia.

Kemajuan teknologi dan dengan berkembangnya secara cepat kebudayaan dari luar sekarang ini menyebabkan terjadinya perubahan pandangan masyarakat terhadap suatu hal termasuk di dalamnya mengenai penerapan hukum dalam hal ini juga termasuk lapangan hukum perkawinan campuran. Karena telah banyaknya terjadi perkawinan campuran di Indonesia dimana tidak hanya terjadi di kota-kota besar tapi juga 
daerah lain di belahan bumi nusantara. Maka berdasarkan hal tersebut di atas penulis tertarik untuk meneliti beberapa permasalahan, yaitu (1) Bagaimana perjalanan perkawinan campuran di Indonesia? (2) Bagaimana fungsi dan peranan Dinas Kependudukan dan Catatan Sipil dalam penerbitan akta perkawinan? (3) Apa saja akibat hukum yang ditimbulkan dari perkawinan campuran ini? Tujuan penulisan ini adalah untuk: mengetahui perjalanan perkawinan campuran di Indonesia, untuk mengetahui fungsi dan peranan Dinas Kependudukan dan Catatan Sipil dalam penerbitan akta perkawinan dan untuk mengetahui akibat hukum yang ditimbulkan dari perkawinan campuran di Indonesia. Sehingga memberikan masukan di dalam problematikan perkawinan campur di Indonesia.

\section{METODE PENELITIAN}

Penelitian karya ilmiah ini, berjenis penelitian hukum normatif (yuridis normatif), yaitu penelitian yang bertujuan untuk meneliti asas-asas hukum, sistematika hukum, sinkronisasi hukum, sejarah hukum dan perbandingan hukum, penelitian ini difokuskan untuk mengkaji dan meneliti materi hukum peran lembaga catatan sipil terhadap perkawinan campuran berdasarkan undang-undang perkawinan. Johnny Ibrahim menyatakan bahwa nilai ilmiah suatu pembahasan dan pemecahan masalah terhadap legal issue yang diteliti sangat tergantung kepada cara pendekatan (approach) yang digunakan (Sonata, 2014).

\section{HASIL DAN PEMBAHASAN}

\section{Dinamika Perkawinan Campuran Di Indonesia}

Manusia dengan jenis laki-laki dan jenis perempuan akan menimbulkan rasa saling tertarik satu sama lainnya untuk hidup bersama merupakan kodrat alam (Sochmawardiah, 2013). Hal seperti ini merupakan salah satu faktor pendorong, sehingga dua orang yang berlainan jenis ini akan melakukan perkawinan. Perkawinan merupakan hal yang bersifat sakral dang sangat penting dalam masyarakat. Menurut Pasal 1 UU 1 Tahun 1974 menyatakan "Perkawinan adalah ikatan lahir dan bathin antara seorang pria dan seorang wanita sebagai suami istri dengan tujuan membentuk keluarga (rumah tangga) yang bahagia dan kekal berdasarkan Ketuhanan Yang Maha Esa”

Perkawinan yang bertujuan membentuk keluarga yang bahagia dan kekal dapat diartikan bahwa perkawinan itu haruslah berlangsung seumur hidup dan tidak boleh diputuskan begitu saja. Dalam praktek dapat dilihat adanya bentuk perkawinan lain seperti perkawinan campuran, sebagaimana yang disebutkan dalam Pasal 57 sampai dengan Pasal 62 UU 1 tahun 1974. Pasal 57 UU 1 tahun 1974 menyatakan pengertian perkawinan campuran adalah perkawinan antara dua orang yang di Indonesia tunduk pada hukum yang berlainan, karena perbedaan kewarganegaraan dan salah satu pihak berkewarganegaraan asing dan salah satu pihak berkwarganegaraan Indonesia (Tanuwidjaja, 2015). 
Laurensius Arliman S: Peran Lembaga Catatan Sipil Terhadap Perkawinan Campuran...

Jadi konkritnya perkawinan campuran menurut undang-undang ini adalah: 1) Seorang pria Warga Negara Indonesia kawin dengan seorang wanita Warga Negara Asing; dan 2) Seorang wanita Warga Negara Indonesia kawin dengan pria Warga Negara Asing. Definisi dari Pasal 1 GHR sangat luas jangkauannya, tidak hanya membatasi arti perkawinan campuran pada perkawinanperkawinan antara warga negara Indonesia atau antar penduduk Indonesia dan perkawinan yang dilangsungkan di Indonesia, asalkan pihak-pihak yang melangsungkan perkawinan di Indonesia tunduk pada hukum yang berlainan (Yohanis, 2018). Dengan adanya pembatasan pada perbedaan kewarganegaraan itu, maka perkawinan antara dua orang yang berlainan golongan (bumi putra dan timur asing) atau berlainan agama (Islam dan Kristen) tapi sama-sama Indonesia, tidak termasuk perkawinan campuran menurut UndangUndang Perkawinan tapi menurut GHR adalah merupakan perkawinan campuran.

Secara teoritis dalam Hukum Perdata Internasional dikenal dua pandangan utama yang berusaha membatasi pengertian perkawinan campuran, yaitu: 1) Pandangan yang beranggapan bahwa suatu perkawinan campuran adalah perkawinan yang berlangsung antara pihak-pihak yang berbeda domisilinya, sehingga terhadap masing-masing pihak berlaku kaidah hukum intern dari dua sistem hukum yang berbeda; 2) Pandangan yang beranggapan bahwa suatu perkawinan dianggap sebagai perkawinan campuran apabila para pihak berbeda kewarganegaraan atau nasionalitasnya. Pandangan yang kedua ini dianut oleh hukum perkawinan nasional Indonesia seperti yang terdapat pada Pasal 57 UU 1 tahun 1974. Pasal lain yang menyangkut perkawinan campuran terdapat dalam UndangUndang Nomor 62 Tahun 1958 adalah Pasal 8 Ayat (1), yaitu sejak satu tahun pernikahannya dengan Warga Negara Asing, maka perempuan Warga Negara Indonesia bisa menyatakan mengubah status kewarganegaraanya mengikuti suami atau tetap menjadi Warga Negara Indonesia.

Setelah lahirnya Undang-Undang Nomor 1 Tahun 1975, maka pengertian dari perkawinan campuran menjadi lebih sempit daripada pengertian yang ada selama ini, baik menurut ilmu hukum maupun yuriprudensi tentang perkawinan campuran sebelum diundangkannya UU 1 tahun 1974 (Sri Budi Purwaningsih, 2014). Pelaksanaan perkawinan campuran ini ada syarat-syarat yang harus dipenuhi oleh para pihak terutama bagi pihak warga negara asing yang akan melangsungkan perkawinan dengan warga negara Indonesia. Syarat-syarat tersebut diperlukan untuk pelaksanaan pencatatan perkawinan. Syarat-syarat tersebut diperlukan untuk pelaksanaan pencatatan perkawinan. Syarat-syarat tersebut antara lain: 1) Akta kelahiran atau akta kenal lahir; 2) Foto copy paspor, Surat Bukti Pendaftaran Orang Asing (SBPOA), Surat Tanda Melapor Diri (STMD), Surat Keterangan 
Kependudukan (SKK) dari imigrasi; 3) Surat keterangan belum pernah kawin dari duta atau dari kantor catatan sipil negara asalnya dan yang telah menjadi penduduk Indonesia mendapat surat keterangan dari lurah; 4) Kartu Tanda Penduduk dan Kartu Keluarga; 5) Foto Copy pajak asing; 6) Pas Foto ukuran 4x6 sebanyak dua lembar; 7) Saksi dua orang yang memiliki KTP; 8) Akta cerai atau akta kematian bagi janda; dan 9) Akta kelahiran anak bagi calon penganten yang telah mempunyai anak, karena sebelumnya kawin adat.

Menurut ketentuan UU 1 tahun 1974 jenis dari perkawinan campuran tersebut hanya satu macam yaitu perkawinan antara warga negara Indonesia dengan orang bukan warga negara Indonesia. Dalam praktek yang sebenarnya perkawinan campuran itu juga terjadi antara orang yang berbeda agama, tetapi undang-undang ini tidak mengaturnya, sehingga hal ini menimbulkan silang pendapat antara para ahli tentang perkawinan campuran (Handayani, 2014). Staatblads 1898 No 158 mengenai jenisjenis perkawinan campuran dapat kita bedakan atas beberapa macam yang secara garis besarnya dinyatakan dalam Pasal 1 GHR, yaitu bahwa yang dimaksud perkawinan campuran adalah perkawinan antara orang-orang yang di Indonesia tunduk pada hukum-hukum yang berlainan. Jadi setiap perkawinan yang dilaksanakan oleh orang yang menganut sistem hukum yang berbeda termasuk perkawinan campuran menurut undangundang ini.
Adapun jenis-jenis perkawinan campuran menurut S. 1989 Nomor 158 adalah sebagai berikut: 1) Perkawinan Campuran Antar Tempat (interlocal). Menurut ketentuan Pasal 1 GHR bahwa yang dinamakan perkawinan campuran adalah antara orang-orang yang ada di Indonesia tunduk hukum-hukum yang berlainan. Dalam hal ini perkawinan antar tempat termasuk kedalam pengertian campuran menurut pasal ini. Perkawinan campuran jenis ini dapat kita contohkan pada perkawinan seorang pria Batak dan seorang wanita Minangkabau. Atau lebih tepat dapat dikatakan sebagai perkawinan beda suku atau adat (Yuni, 2010). Dalam pelaksanaan perkawinan ini dahulunya tidak dilarang dalam adat, tetapi dianggap sebagai suatu kebiasaan; 2) Perkawinan Campuran Antar Agama (Interreligius). Sampai sekarang ini ada pendapat yang mengemukakan bahwa terdapat kekosongan hukum dalam UU 1 tahun 1974, hal ini disebabkan karena sampai sekarang perkawinan antara agama masih belum memenuhi titik temu. Ini dikarenakan perkawinan beda keyakinan (agam) tidak bisa dilakukan di Indonesia, bahkan dalam islam sendiri terdapat dua pendapat antara membolehkan dan tidak membolehkan dilakukannya perkawinan campuran antar agama; 3) Perkawinan Campuran Antar Golongan (Intergentiel). Perkawinan antar golongan adalah perkawinan yang dilaksanakan antara laki-laki bukan eropa dengan wanita eropa. Pada masyarakat colonial Hindia Belanda dulunya masyarakat dibagi atas tiga golongan, yang hidupnya agak terpisah satu sama lainnya (Yuni, 2010). 
Laurensius Arliman S: Peran Lembaga Catatan Sipil Terhadap Perkawinan Campuran...

\section{Fungsi Dan Peranan Dinas Kependudukan dan Catatan Sipil Dalam Penerbitan Akta Perkawinan}

Akta catatan sipil merupakan suatu hal yang sangat penting dan perlu karena dengan akta catatan sipil orang dapat dengan mudah memperoleh kapasitas akan kejadian-kejadian seperti kelahiran, kematian, perkawinan, perceraian, pengakuan anak, pengesahan anak dan pergantian nama. Hal ini sesuai dengan tujuan dari lembaga catatan sipil itu sendiri yaitu suatu lembaga yang memberikan kepastian hukum yang sebesar-besarnya, selengkap-lengkapnya serta sejelas-jelasnya akan kejadian atau peristiwa atau kejadian sendiri maupun orang lain yang berkepentingan mempunyai bukti atau kepastian hukum tentang peristiwa atau kejadian tersebut. Catatan sipil mengandung arti suatu lembaga yang ditugaskan untuk memelihara daftar-daftar atau catatancatatan guna pembuktian status atau peristiwa-peristiwa penting bagi warga negara, atau dapat pula dikatakan bahwa lembaga catatan sipil adalah suatu lembaga atau badan pemerintah yang ditugaskan mencatat dalam suatu daftar tertentu peristiwa-peristiwa yang mempunyai arti penting bagi status keperdataan seperti kelahiran, kematian, perkawinan, pengakuan anak, pengesahan anak, perceraian dengan maskut untuk dipergunakan sebagai pembuktian tentang adanya atau telah terjadinya peristiwaperistiwa tersebut.
Semua akta yang dikeluarkan oleh lembaga catatan sipil adalah akta otentik yang mengandung kebenaran murni, mempunyai kekuatan hukum dan kepastian hukum. tidak dapat dikatakan palsu sebelum dinyatakan oleh Pengadilan Negeri dengan ketetapan atau keputusannya dan tidak dapat di ralat atau dibatalkan ataupun diperbaharui atas izin Pengadilan Negeri serta mengikat semua pihak (Putri, 2018). Dengan demikian akta catatan sipil tersebut merupakan hal yang sangat menentukan akan kebenaran dari suatu permasalahan apabila diperkarakan. Dan dalam lingkungan internasional pun, akta catatan sipil mendapat pengakuan yang sah.

Kelahiran UU 1 tahun 1974 dan PP 7 Tahun 1975 maka berdampak langsung dan mempengaruhi lembaga catatan sipil. Akibatnya lembaga catatan sipil mengalami perkembangan yang sangat pesat dalam mencatat perkawinan di Indonesia. Hal ini terlihat dari Pasal 2 Ayat (1) dan ayat (2) PP 7 Tahun 1975 yang menentukan bahwa pencatatan perkawinan dari mereka yang melangsungkan perkawinan menurut agama Islam dilakukan oleh Pegawai Pencatatan.

Perkawinan dari mereka yang melangsungkan perkawinan itu selain agama Islam dilakukan oleh Pegawai Pencatatan Perkawinan pada Kantor Catatan Sipil sebagaimana dimaksud dalam berbagai perundang-undangan mengenai pencatatan perkawinan. Adapun kegiatan dari akta-akta yang dibuat di catatan sipil yang dapat kita rasakan 
manfaatnya adalah sebagai berikut ( $\mathrm{S}$, 2016): 1). Akta catatan sipil merupakan alat bukti yang paling kuat dalam menentukan kedudukan hukum seseorang; 2) Merupakan akta otentik yang mempunyai kekuatan hukum pembuktian sempurna didepan hakim atau pengadilan; 3) Memberikan kepastian hukum yang sebesar-besarnya tentang kejadian-kejadian mengenai kelahiran, kematian, perkawinan, perceraian, pengakuan anak dan pengesahan anak; 4) Dari segi praktisnya akta-akta kelahiran pada khususnya dari catatan sipil dapat dipergunakan untuk tanda bukti yang otentik dalam pengurusan paspor kewarganegaraan, Kartu Tanda Penduduk, keperluan sekolah, bekerja menentukan status waris dan lain sebagainya.

Mengenai fungsi dari lembaga catatan sipil itu sendiri seperti yang terdapat dalam Keputusan Presiden No 12 Tahun 1983, kantor catatan sipil mempunyai fungsi menyelenggarakan: 1) Pencatatan dan penerbitan kutipan akta kelahiran; 2) Pencatatan dan penerbitan kutipan akta perkawinan; 3) Pencatatan dan penerbitan kutipan akta perceraian; 4) Pencatatan dan penerbitan kutipan akta pengakuan anak dan pengesahan anak; 5) Pencatatan dan penerbitan kutipan akta kematian; 6) Penyimpanan dan pemeliharaan akta kelahiran, akta perkawinan, akta perceraian, akta pengangkatan dan akta pengesahan anak serta akta kematian; dan 7) Penyediaan bahan dalam rangka perumusan kebijaksanaan di bidang kewarganegaraan dan kependudukan.

Mengingat arti penting dari akta catatan sipil ini bagi pemerintah dan warga masyarakat sendiri, maka terdapat ketentuan-ketentuan pidana yang berhubungan dengan pelaksanaan catatan sipil, seperti yang terdapat dalam Pasal 61 Ayat (2) dan Ayat (3) UU 1 tahun 1974. Ayat (2) berbunyi "barang siapa melangsungkan perkawinan campuran tanpa memperlihatkan lebih dahulu kepada pegawai pencatat yang berwenang surat keterangan atau keputusan pengganti keterangan yang disebut dalam Pasal 60 Ayat (4) undang-undang ini dihukum dengan hukuman kurungan selamalamanya 1 (satu) bulan" dan ayat (3) yang berbunyi "pegawai pencatat perkawinan yang mencatat perkawinan sedangkan ia mengetahui bahwa keterangan atau keputusan pengganti keterangan tidak ada, dihukum dengan hukuman kurang selama-lamanya 3 (tiga) bulan dan dihukum jabatan".

Adapun ketentuan-ketentuan pidana lain yang berhubungan dengan catatan sipil antara lain: 1) Pasal 45 ayat (1) dan ayat (2) Peraturan Pemerintah Nomor 9 Tahun 1975; 2) Pasal 436 ayat (1) dan ayat (2) Kitab Undang-Undang Hukum Pidana (KUHP); 3) Pasal 529 KUHP; 4) Pasal 555 sampai dengan Pasal 559 KUHP. Dari hal-hal yang disebutkan di atas dapatlah kita pahami bahwa catatan sipil mempunyai peran penting dalam hal penerbitan akta-akta yang dalam kajian kali ini adalah akta perkawinan. Akta ini nantinya akan dijadikan sebagai data-data 
Laurensius Arliman S: Peran Lembaga Catatan Sipil Terhadap Perkawinan Campuran...

konkrit yang bisa dipakai dalam hal pendataan kependudukan. Selain untuk kepentingan dari pemerintah catatan sipil juga dijadikan bukti tertulis dan otentik bagi setiap warga masyarakat tentang peristiwa yang terjadi pada dirinya.

\section{Akibat Hukum Yang Ditimbulkan Dari Perkawinan Campuran}

Sebelum membahas akibat hukum yang timbul dari perkawinan campuran ini ada baiknya diketahui terlebih dahulu asas-asas utama yang berkembang dalam Hukum Perdata Internasional tentang hukum yang digunakan dalam mengatur validitas material dari suatu perkawinan campuran, yaitu (Situngkir, 2018): 1) Asas lex loci celebrationis yang bermakna bahwa validitas material dari suatu perkawinan campuran harus ditetapkan berdasarkan kaidah hukum dari tempat dimana perkawinan itu diresmikan atau dilangsungkan; 2) Asas yang menyatakan bahwa validitas material suatu perkawinan ditentukan berdasarkan sistem hukum dari tempat masing-masing pihak menjadi warga negara sebelum perkawinan dilangsungkan; 3) Asas yang menyatakan bahwa validitas material perkawinan harus ditentukan berdasarkan dari sistem hukum dari masing-masing pihak berdomisili sebelum perkawinan dilangsungkan; dan 4) Asas yang menyatakan bahwa validitas perkawinan harus ditentukan berdasarkan sistem hukum dari tempat dilangsungkannya perkawinan (locus celebrationis), tanpa mengabaikan persyaratan perkawinan yang berlaku di dalam sistem hukum para pihak sebelum perkawinan dilangsungkan.

Adapun permasalahan atau akibat hukum yang timbul dari perkawinan campuran ini dapat dibagi atas dua permasalahan, yaitu:

\section{a) Akibat Hukum Terhadap Pihak- Pihak Yang Melakukan Perkawinan Campuran}

Undang-undang Kewarganegaraan, secara tidak langsung telah menempatkan perempuan Indonesia sebagai pihak yang harus dirugikan dengan kehilangan kewarganegaraanya serta kehilangan hak atas pemberian kewarganegaraan pada keturunannya. Bagi-bagi yang berlainan kewarganegaraan yang melaksanakan perkawinan campuran, dapat memperoleh kewarganegaraan dari suami atau istrinya dan dapat pula kehilangan kewarganegaraanya menurut cara-cara yang ditentukan oleh Undang-Undang Kewarganegaraan Republik Indonesia. Seorang perempuan Warga Negara Indonesia yang kawin dengan laki-laki Warga Negara Asing kehilangan kewarganegaraan Indonesia-nya, apabila dalam waktu satu tahun setelah perkawinannya berlangsung, menyatakan keterangan untuk itu, kecuali apabila ia dengan kehilangan kewarganegaraan Republik Indonesia itu ia menjadi tanpa kewarganegaraan (Sartini, 2016).

Sejak satu tahun pernikahannya dengan Warga Negara Asing, maka perempuan Indonesia bisa menyatakan mengubah status kewarganegaraanya mengikuti suami atau tetap menjadi 
Warga Negara Indonesia. Hal ini memungkinkan terjadinya perbedaan kewarganegaraan antara suami dan istri. Jika pasangan kawin campur tersebut tinggal di negara suami atau istri, maka ada akibat yang timbul dari perbedaan kewarganegaraan tersebut, yaitu (Ibarhim, Nurbaeti, 2012): 1) Hambatan imigrasi; 2) Status istri yang rentan sebagai imigran di negara suami; 3) Dalam masa apikasi sebagai permanen resident perempuan rentan terhadap kekerasan domestik dan sistem hukum yang tidak memihak; 4) Jika tinggal di negara istri, istri tidak dapat mensponsori suami; 5) Apabila karena satu hal suami dideprtasi, anak secara otomatis akan ikut terdeportasi pula.

Hal ini menjadi dilema bagi perempuan Indonesia, apakah ikut suaminya atau tetap tinggal di tanah air. Bagi perempuan Indonesia yang tinggal di negara suami, perbedaan kewarganegaraan dengan suami atau dengan anaknya memaksa mereka untuk mengubah kewarganegaraan agar memperoleh perlindungan hukum. Apabila terjadi perpisahan karena perceraian atau kematian, maka ia bisa tinggal bersama anaknya. Memang bagi sebagian orang bangga bisa memperoleh kewarganegaraan asing, tapi ada suatu ungkapan atau pameo yang menyatakan bahwa semakin dekat ia pada keputusan untuk mengubah kewarganegaraanya semakin cinta ia pada paspor-nya. Perlu kita ketahui bahwa kewarganegaraanya bukan sekedar paspor, tetapi menyangkut hak sipil, ekonomi, politik, sosial dan kultural di tanah air yang ia jaga. Selain itu mengubah status kewarganegaraan menjadi sama dengan suami bukannya tetap beresiko karena di negara tertentu kehilangan kewarganegaraan pada suami akan berpengaruh pula kepada istri yang menyebabkan statusnya menjadi stateless atau tanpa kewarganegaraan.

Berbagai perlindungan hukum yang seyogyanya diberikan kepada ibu Warga Negara Indonesia telah dicoba dirancang seperti seperti dalam Undang-Undang Nomor 17 Tahun 2016 Perubahan Kedua Undang-Undang Nomor 23 Tahun 2002 Tentang Perlindungan Anak (Farid, 2015). Dalam hal ini putusnya perkawinan akibat perceraian di atur adanya kemungkinan bagi negara melalui pengadilan negeri atas permohonan ibu Warga Negara Indonesia untuk mengganti kewarganegaraan anak menjadi Warga Negara Indonesia atau usulan adanya perjanjian pra-nikah yang mengatur tentang kewarganegaraan anak dalam Undang-Undang Kewarganegaraan. Namun pada kenyataannya pengaturan itu hanya sebagai pemanis dan sangat implementatif (Kustini, 2013) .

Persoalan lain yang muncul adalah mengenai terjadinya kekerasan terhadap perempuan. Perempuan Warga Negara Asing yang menikah dengan laki-laki Warga Negara Indonesia akan sangat tergantung kepada suaminya karena keberadaanya berdasarkan sponsor dari suami. Begitu juga bila perempuan Warga Negara Indonesia menikah dan tinggal di negara asal suami menjadi rentan terhadap kekerasan dari suami sebab 
Laurensius Arliman S: Peran Lembaga Catatan Sipil Terhadap Perkawinan Campuran...

hukum Indonesia tidak membolehkan kewarganegaraan ganda sehingga hukum di negara suami tidak dapat melindungi istri yang Warga Negara Indonesia. Sedangkan aturan yang ada di dalam Undang-Undang Kewarganegaraan adalah bila perempuan Warga Negara Asing menikah dengan laki-laki Warga Negara Indonesia, maka setahun setelah pernikahan dapat mengajukan menjadi Warga Negara Indonesia asal melepas Warga Negara Asing-nya (Martinelli, 2016).

Sebagaimana kita ketahui hak perempuan Warga Negara Indonesia telah diakui secara konstitusional melalui Undang-Undang Nomor 7 tahun 1984 tentang Ratifikasi Konvensi tentang Penghapusan Segala Bentuk Diskriminasi terhadap Perempuan dan Undang-Undang Nomor 39 Tahun 1999 tentang Hak Asasi Manusia (Komnas Perempuan, 2010). Dari hal diatas dapatlah kita pahami bahwa sudah saatnya perempuan Warga Negara Indonesia menjadi warga negara kelas satu dalam sistem hukum Indonesia, itupun jika negara hendak menyempurnakan hukum Indonesia dan memajukan Hak Asasi Manusia.

\section{b) Akibat Hukum Terhadap Anak Yang Lahir Dari Perkawinan Campuran}

Kehadiran anak dalam suatu perkawinan merupakan suatu hal yang dinanti dari setiap pasangan, karena salah satu tujuan dilakukan perkawinan tersebut adalah untuk melanjutkan atau mendapatkan keturunan. Dalam perkawinan campuran anak juga merupakan pihak yang secara tidak langsung mendapatkan masalah, terlebih mengenai status kewarganegaraan dari si anak. Di dunia ini dikenal dua sistem atau asas penentuan kewarganegaraan, yaitu ius sanguinis (berdasarkan keturunan) dan ius soli (berdasarkan tempat kelahiran). Peraturan kewarganegaraan Indonesia mengikuti garis keturunan ayah seperti yang dinyatakan bahwa secara otomatis anak yang lahir dari perkawinan antara perempuan Warga Negara Indonesia yang kawin dengan Warga Negara Asing akan mengikuti ayahnya. Kecuali di negara ayah tidak dapat memberi kewarganegaraan kepada anak yang lahir dari perkawinan campuran itu, sehingga mengakibatkan anak itu menjadi tidak mempunyai kewarganegaraan. Dalam hal ini si ibu dapat mengajukan permohonan melalui pengadilan agar anak tersebut memperoleh kewarganegaraan mengikuti ibunya.

Apabila terjadi putusnya perkawinan akibat perceraian tidak mengakibatkan putusnya hak asuh kedua orang tua terhadap anak, artinya implementasi Undang-Undang Perlindungan Anak harus melibatkan izin dari ayah yang Warga Negara Asing dan negara asing dimana si anak menjadi warga negaranya untuk menyetujui pelepasan kewarganegaraan anak. Secara procedural hal ini berbelit-belit serta memakan biaya dan waktu. Selama ini perbedaan kewarganegaraan antara ibu dan anak dalam perkawinan campuran telah melahirkan berbagai kesulitan bagi perempuan Warga Negara Indonesia. 
Dimana ia harus mengurus izin tinggal anaknya dengan visa kunjungan sosial atau budaya, maka biaya yang keluar dari proses itu adalah biaya permohonan visa, perjalanan ke luar Indonesia untuk mengambil visa, menunggu proses selama dua hari kerja, melaporkan kedatangan, perpanjangan visa setiap bulan, pelaporan orang asing, setelah enam bulan mengajukan permohonan izin tinggal baru dan perjalanan ke luar Indonesia selama tiga hari.

Jika keberadaan anak Warga Negara Asing tidak dilaporkan karena ketidaktahuan atau karena tidak mampu, maka pilihannya adalah membayar denda overstay, anak didepotasi, atau dalam Undang-Undang Keimigrasian dikenai pidana dengan tuduhan menyembunyikan orang secara illegal (Darda Pasmatuti, 2017). Bagi perempuan Warga Negara Indonesia yang tinggal di negara suami, perbedaan kewarganegaraan mereka agar memperoleh perlindungan hukum. Apabila terjadi perpisahan baik karena perceraian atau kematian maka ia tetap bisa tinggal bersama anaknya. Dalam Undang-Undang Kewarganegaraan anak yang lahir dari perkawinan campuran bisa memperoleh kewarganegaraan dari ayah atau ibunya yang ditetapkan melalui perjanjian pranikah. Perjanjian pranikah tentu saja memerlukan syarat-syarat tertentu, syarat-syarat ini potensial menimbulkan masalah baru, yaitu timbul biaya notaris dan masalah akses informasi serta layanan hukum untuk membuat perjanjian pranikah bagi perempuan yang tinggal di pelosok atau perempuan yang berpendidikan rendah. Selain itu, menutup kemungkinan bagi perempuan yang sudah terlanjur menikah dengan Warga Negara Asing yang ingin menjadikan anaknya Warga Negara Indonesia.

\section{SIMPULAN}

Aspek hukum dari catatan sipil adalah untuk memperoleh suatu kepastian hukum yang sebesar-besarnya tentang peristiwa-peristiwa pribadi. Lembaga catatan sipil adalah lembaga pemerintahan, lembaga administrasi negara yang bertugas, berfungsi mencatat segala peristiwa keluarga dan berhak, berwenang menerbitkan ketetapan dalam bidang kependudukan dan kewarganegaraan. Akibat dari pencatatan dan penerbitan ketetapan tersebut, mempunyai kaitan hukum dengan status keperdataan seseorang atau hukum perorangan. Dengan berlakunya UU 1 Tahun 1974 tentang Perkawinan dan PP 9 Tahun 1975 sebagai peraturan pelaksananya, maka kebutuhan masyarakat akan Lembaga Catatan Sipil semakin penting. Catatan sipil telah melakukan tugas yang diembankan oleh negara dengan baik, yaitu dengan cara melayani setiap pihak yang akan melaporkan perkawinan campuran yang dilakukan oleh para pihak dengan sebaikbaiknya, yang jadi permasalahan adalah kurang kesadaran masyarakat akan arti pentingnya pelaporan tersebut.

Pelaksanaan perkawinan campuran dapat dilakukan apabila para pihak telah memenuhi semua persyaratan yang ditentukan oleh undang-undang sebagaimana yang terdapat dalam Pasal 
Laurensius Arliman S: Peran Lembaga Catatan Sipil Terhadap Perkawinan Campuran...

60 Ayat (1) UU 1 Tahun 1974. Sedangkan Lembaga Catatan hanya bertugas untuk mencatatkan peristiwa perkawinan campuran tersebut. Setiap perbuatan hukum yang dilakukan oleh setiap orang tertentu saja mempunyai dampak atau akibat baik itu bagi dirinya ataupun bagi pihak lainnya. Tidak terkecuali dalam perkawinan campuran ada akibat hukum yang ditimbulkannya, baik itu bagi pihakpihak pelaku perkawinan campuran maupun bagi anak yang lahir dari perkawinan campuran tersebut.

\section{DAFTAR PUSTAKA}

Damayanti, R. (2015). Kajian Akademis Rencana Program 30 Tahun Menghadirkan Manusia Indonesia Baru (Peluang Pengkondisian Perkawinan Antar Etnis, Ras, Bangsa dan Agama Di Indonesia). Jakarta: Kementerian Pemberdayaan Perempuan dan Perlindungan Anak Pusat Penelitian Kesehatan Universitas Indonesia.

Darda Pasmatuti. (2017). Analisa Terhadap Putusan Mahkamah Konstitusi No 46/PUU-VIII/2010 Mengenai Status Anak. Jurnal Cendikian Hukum, 3(1).

Farid, M. (2015). Interpretasi Hakim Tentang Anak Di Luar Kawin Pasca Putusan MK 46/PUU-VIII/2010 Tentang Pengakuan UU 1 Tahun 1974 Tentang Perkawinan (Studi di Pengadilan Agama Purwekerto). Jurnal Idea Hukum, 1(2).

Fauzi, R. (2018). Perkawinan Campuran Dan Dampak Terhadap Kewarganegaraan Dan Status Anak Menurut Undang-Undang Di
Indonesia. Soumatera Law Review, l(1).

Handayani, R. (2014). Perkawinan Beda Agama Dipandang Dari Hukum Islam. Parental, 1(3).

HS, S. (2002). Pengantar Hukum Perdata Tertulis $(B W)$. Jakarta: Sinar Grafika.

Ibarhim, Nurbaeti, Y. (2012). Tinjauan Yuridis Hak Anak Dari Perkawinan Siri Pasca Putusan Mahkamah Konstitusi No 46/PUU-VIII/2010. Jurnal Legalitas, 3(2).

Jasmir. (2018). Pengembalian Status Hukum Tanah Ulayat Atas Hak Guna Usaha. Soumatera Law Review, 1(1).

Kustini. (2013). Menelusuri Makna Di Balik Fenomena Perkawinan Di Bawah Umur Dan Perkawinan Tidak Tercatat. Jakarta: Kementerian Agama RI Badan Litabang Dan Diklat puslitbang Kehidupan Keagamaan.

Laurensius Arliman S, F. D. (2015). Dispensasi Perkawinan Bagi Anak Dibawah Umur Di Pengadilan Agama Padang Sidempuan. Jurnal Al-Adalah, 12(4).

Martinelli, I. (2016). Status Hukum Anak Luar Kawin Pasca Putusan Mahkamah Konstitusi No 46/PUUVIII/2010. Jurnal De Lega Lata, Jurnal De(1), 2.

Putri, R. P. (2018). Pemeriksaan Penggabungan Gugatan Ganti Kerugian Dalam Perkara Pidana Di Pengadilan Negeri Kelas 1B Bukittinggi. Soumatera Law Review, 1(1). 
Rahmat Fauzi, F. (2018). Efektifitas Mediasi Dalam Menyelesaikan Sengketa Perceraian (Study Di Pengadilan Agama Bukittinggi Dan Pengadilan Agama Payakumbuh Tahun 2015-2017). Soumatera Law Review, 1(2).

S, L. A. (2016). Lembaga-Lembaga Negara Independen (Di Dalam Undang-Undang Dasar Negara Republik Indonesia Tahun 1945). Yogyakarta: Deepublish.

Sartini, A. B. A. dan S. (2016). Kriminalisasi Nikah Siri Dalam Persepktif Nikah Siri Dalam Perspektif Hukum Pidana. Jurnal Legalitas, 8(1).

Situngkir, D. A. (2918). Asas Legalitas Dalam Hukum Pidana Nasional Dan Hukum Pidana Internasional. Soumatera Law Review, 1(1).

Sochmawardiah, R. A. (2013). Perlindungan Hukum Dari Diskriminasi Rasial Di Indonesia Pada Era Reformasi. Universitas Indonesia.

Sonata, D. L. (2014). Metode Penelitian Hukum Normatif Dan Empiris: Karakteristik Khas Dari Metode Meneliti Hukum. Fiat Justisia JJurnal Ilmu Hukum, 8 (1), 15-35.
Sri Budi Purwaningsih. (2014). Perlindungan Hukum Kedudukan Anak Luar Kawin Pasca Putusan Mahkamah Konstitusi No 46/PUUVIII/2010. Rechtsidee, 1(1).

Tanuwidjaja, T. H. (2015). Politik Hukum Putusan Pengadilan Agama Yang Menyimpangi Pasal 105 (a) KHI Tentang Hak Asuh Anak Yang Belum Mumayyiz Dalam Kasus Perceraian Marshanda dan Ben Kasyafani. Refleksi Hukum, 9(1).

Yohanis. (2018). Perkawinan Poligami Di Wilayah Hukum Pengadilan Agama Kota Padang (Mekanisime Pemberian Izin, Dasar Hukum, Syarat-Syarat Poligami Dan Pelaksanaanya). Soumatera Law Review, 1(1).

Yuni, L. A. (2010). Kompatibilitas KHI Dengan Konvensi Perempuan. Mimbar Hukum, 22(2).

Yunita, T. L. (2008). Peranan Komisi Perlimdungan Anak Indonesia (KPAI) Terhadap Perlindungan Hak Asuh Anak Akibat Perceraian. Universitas Islam Negeri Syarif Hidayatulah. 